\title{
CDC73 Gene
}

National Cancer Institute

\section{Source}

National Cancer Institute. CDC73 Gene. NCI Thesaurus. Code C43569.

This gene is involved in transcription and may play a role in cell cycle progression. 